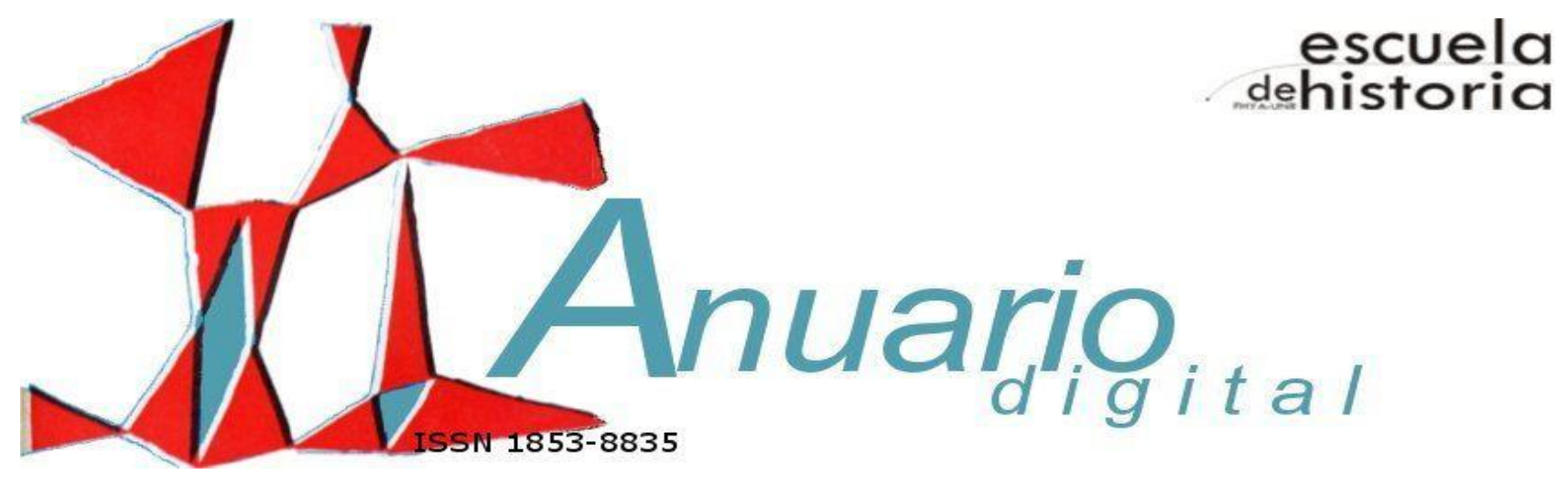

\title{
UNAS PALABRAS DEL COMITÉ EDITOR
}

Entre fines del 2017 y principios de 2018 perdimos a dos queridas colegas y amigas; Gabriela Dalla Corte Caballero (1968/2017) y María del Rosario (Tatato) Baravalle (1951/2018).

Gabriela se recibió de Licenciada y Profesora en Historia, luego de Master en Género en la Universidad Nacional de Rosario, donde realizó sus primeras experiencias docentes e investigativas para radicarse luego en España y concretar dos doctorados, dictar clases en la Universitat de Barcelona y desempeñarse como profesora titular desde 2008. Desarrolló una importante obra académica y permaneció sostenidamente vinculada a nuestra Escuela a través de innumerables iniciativas siempre desde un gesto profundamente generoso y colaborativo.

Tatato se graduó como Profesora y Licenciada en la UNR y reingresó a la universidad luego de la última dictadura militar argentina para desarrollar su carrera en el ámbito de la historia americana colonial hasta su jubilación; momento en que se desempeñaba como Profesora Titular de Historia de América Il. Fue miembro del Centro de Estudios Sociales Regionales (CESOR) y del Centro de Estudios de la Diversidad Cultural (CEDCU) en la UNR, secretaria de redacción de distintas publicaciones académicas y cofundadora codirectora y editora de Prohistoria. Mantuvo una importante presencia en la vida de la Escuela de Historia a lo largo de tres décadas, siempre participando en instancias colectivas que se amigaban con la de algunos de los sujetos de la historia que escribía. 
Desde ese lazo humano construido a lo largo de muchos años en la experiencia de transitar y sostener la universidad pública es que el Comité editor del ANUARIO quiere rendir un pequeño homenaje a nuestras queridas Tatato y Gabriela.

183

Anuario № 30, Escuela de Historia

Facultad de Humanidades y Artes (Universidad Nacional de Rosario), 2018

pp. $182-182$

ISSN 1853-8835 